\title{
Clinical experience with left main coronary artery stenosis
}

\author{
S. O. Banim, R. M. Donaldson, D. C. Russell, M. F. Sturridge, J. E. C. Wright, M. Honey, \\ and R. Balcon
}

From the London Chest Hospital

We report the clinical features and the results of investigation and surgery in 20 patients with significant left main coronary artery stenosis. All had moderate to severe angina; 8 had pain at rest. Three had dyspnoea as a major symptom.

The electrocardiogram zoas abnormal in 17, with evidence of previous myocardial infarction in 10. Of the 11 patients exercised, 8 developed chest pain. Nine patients had a normal left ventriculogram.

At coronary angiography all patients had major disease elsewhere in addition to the left main coronary artery stenosis. There were no deaths or major complications associated with this investigation.

One patient was unsuitable for surgery because of diffuse left ventricular hypokinesia, one had a fatal myocardial infarction while awaiting operation, and there was one peroperative death. Sixteen of the 17 surgical survivors are free from angina. There has been a significant improvement in the maximum exercise capacity in the 10 patients who had pre- and postoperative exercise tests.

Stenosis of the main stem of the left coronary artery carries a poor prognosis, with less than half the medically treated patients surviving 5 years after diagnosis (Bruschke, Proudfit, and Sones, 1973; Webster, Moberg, and Rincon, 1974; Cohen et al., 1972). The earlier reports on investigation and surgery in patients with this lesion suggest that both are associated with a high mortality (Cohen et al., 1972; Lavine et al., 1972).

In the four-year period, November 1970 to October 1974, we investigated angiographically 665 patients with suspected coronary artery disease. Twenty of these had stenosis of the left main coronary artery of more than 75 per cent. The clinical features and the results of investigations and surgery in this group are reported.

\section{Methods}

The investigation protocol followed has been reported previously (Balcon et al. . 1974). Angina and dyspnoea were graded from 1 to 4 , using the same criteria as the New York Heart Association grading for dyspnoea. Routine chest radiographs and electrocardiograms were made. The electrocardiographic diagnosis and localization Received 8 July 1975. of myocardial infarction were based on the criteria of McConahay et al. (1970). The patients had fasting serum cholesterol and triglyceride estimations and lipoprotein electrophoresis, and the lipoprotein abnormality was typed using the World Health Organization classification (1970). Patients performed a standardized exercise test in the upright position on a bicycle ergometer with electrocardiographic recording from a bipolar chest lead. Exercise started at $150 \mathrm{kpm} / \mathrm{min}$ (24.5 Watts) and increased by $150 \mathrm{kpm} / \mathrm{min}$ (24.5 Watts) every two minutes until the development of angina, ST segment depression of $2 \mathrm{~mm}$ or more, dyspnoea, or fatigue.

Left heart catheterization was performed from the right brachial artery after premedication with intramuscular diazepam. The resting left ventricular enddiastolic pressure was recorded and those without chest pain at rest were paced, usually from the right atrium, until the patient developed angina. Left ventriculograms were graded from 0 to 4,0 being normal and 1 to 4 showing an increasing area of abnormal movement. Coronary angiography was performed by the Sones technique in all cases. The angiographic severity of coronary artery disease was represented by a numerical score. Each major vessel was scored on a scale of 0 to 4; 0 was normal, 4 total occlusion, and 1 to 3 stenosis of increasing severity ( 1 less than $50 \%, 250$ to $75 \%$, and 375 to $99 \%$ ).

Operation was usually performed within four weeks of investigation but patients with recurring episodes of rest 


\begin{tabular}{|c|c|c|c|c|c|c|c|c|c|c|c|c|c|c|}
\hline & & & & & & & & & Serum li & lipids & & & & \\
\hline & & & Angina & & & myocar- & & & & & Lipo- & & $\begin{array}{l}\text { Beta-adrener, } \\
\text { blocking agen }\end{array}$ & $\begin{array}{l}\text { rgic } \\
\text { nts }\end{array}$ \\
\hline $\begin{array}{l}\text { Case } \\
\text { no. }\end{array}$ & $\begin{array}{l}\text { Age } \\
(y r)\end{array}$ & Sex & Grade & $\begin{array}{l}\text { Dura- } \\
\text { tion } \\
\text { (mth) }\end{array}$ & $\begin{array}{l}\text { Dysp- } \\
\text { noea }\end{array}$ & $\begin{array}{l}\text { dial } \\
\text { infarc- } \\
\text { tion }\end{array}$ & $\begin{array}{l}\text { Electro- } \\
\text { cardiogram }\end{array}$ & $\begin{array}{l}\text { Chest } \\
\text { radiograph }\end{array}$ & $\begin{array}{l}\text { Choles- } \\
\text { terol } \\
(\mathrm{mg} / \mathrm{dl})\end{array}$ & $\begin{array}{l}\text { Trigly- } \\
\text { cerides } \\
\text { (mg/dl) }\end{array}$ & $\begin{array}{l}\text { protein } \\
\text { abnor- } T \\
\text { mality } t r\end{array}$ & $\begin{array}{l}\text { Trini- } \\
\text { rin }\end{array}$ & Agent & $\begin{array}{l}\text { Dose/day } \\
(m g)\end{array}$ \\
\hline 1 & 49 & $\mathbf{M}$ & 3 & 60 & - & + & AMI and IMI & Normal & & & & + & Propranolol & 240 \\
\hline 2 & 48 & M & 4 & 3 & - & 0 & Normal & Normal & 360 & 288 & Type2b & 0 & - & - \\
\hline 3 & 42 & $\mathbf{M}$ & 2 & 3 & 1 & + & IMI & Normal & 240 & 230 & Type 4 & 0 & - & - \\
\hline 4 & 63 & $\mathbf{M}$ & 2 & 6 & 3 & 0 & IMI & Cor+PVC & 245 & 278 & Type 4 & 0 & - & - \\
\hline 5 & 59 & $\mathbf{M}$ & 4 & 8 & 一 & 0 & $\begin{array}{c}\text { Transient ST } \\
\text { depression }\end{array}$ & Normal & 200 & 285 & Type 4 & + & Practolol & 300 \\
\hline 6 & 59 & $\mathbf{M}$ & 3 & 96 & 3 & + & IMI & $\begin{array}{l}\text { Enlarged } \\
\text { heart, PVC }\end{array}$ & 225 & 207 & Type 4 & + & - & - \\
\hline 7 & 45 & M & 3 & 72 & - & 0 & LBBB & Normal & & & & + & Propranolol & 240 \\
\hline 8 & 51 & $\mathbf{M}$ & 3 & 120 & - & + & IMI & Normal & 175 & 384 & Type 4 & 0 & Practolol & 200 \\
\hline 9 & 51 & F & 2 & 6 & 1 & 0 & ASMI & Normal & 356 & 133 & Type2a & 0 & Propranolol & 60 \\
\hline 10 & 60 & $\mathbf{M}$ & 4 & 36 & - & 0 & $\begin{array}{c}\text { Transient ST } \\
\text { depression }\end{array}$ & Normal & 260 & & & + & Propranolol & 120 \\
\hline $\begin{array}{l}11 \\
12\end{array}$ & 48 & $\begin{array}{l}M \\
M\end{array}$ & $\begin{array}{l}2 \\
2\end{array}$ & $\begin{array}{l}12 \\
60\end{array}$ & 2 & 0 & Normal & Normal & 286 & 220 & Type 4 & + & Practolol & 300 \\
\hline 12 & 49 & $\mathbf{M}$ & 2 & 60 & - & + & ASMI & Normal & & & & 0 & Propranolol & 120 \\
\hline 13 & 52 & $\mathbf{M}$ & 4 & 72 & - & + & AMI & Normal & 164 & & & + & Oxprenolol & 120 \\
\hline 14 & 34 & $\mathbf{F}$ & 4 & 3 & - & 0 & $\begin{array}{c}\text { Transient ST } \\
\text { depression }\end{array}$ & Normal & 242 & 85 & Normal & + & - & - \\
\hline 15 & 47 & $\mathbf{M}$ & 3 & 108 & - & + & $\begin{array}{c}\text { Inverted T } \\
\text { in } V 3-6\end{array}$ & Normal & 260 & 24 & Normal & + & Practolol & 800 \\
\hline 16 & 68 & $\mathbf{M}$ & 2 & 6 & 3 & + & IMI & $\begin{array}{l}\text { Enlarged } \\
\text { heart, PVC }\end{array}$ & 265 & 150 & Normal & 0 & 一 & - \\
\hline 17 & 50 & $\mathbf{M}$ & 4 & 132 & 2 & + & AMI and IMI & $\begin{array}{l}\text { Enlarged } \\
\text { heart }\end{array}$ & & & & + & Oxprenolol & 120 \\
\hline 18 & 66 & $\mathbf{M}$ & 4 & 120 & 一 & 0 & $\begin{array}{c}\text { Transient ST } \\
\text { depression }\end{array}$ & Normal & 275 & & & + & - & - \\
\hline $\begin{array}{l}19 \\
20\end{array}$ & 49 & $\mathbf{M}$ & 2 & 36 & 1 & 0 & Normal & Normal & 190 & 150 & Normal & 0 & - & - \\
\hline 20 & 40 & $\mathbf{M}$ & 4 & 12 & 1 & 0 & $\begin{array}{c}\text { Inverted T } \\
\text { in V3-6 }\end{array}$ & Normal & 235 & 180 & Normal & + & Practolol & 200 \\
\hline
\end{tabular}

AMI, anterior myocardial infarction; IMI, inferior myocardial infarction; LBBB, left bundle-branch block; ASMI, anteroseptal myocardial infarction; PVC, pulmonary venous congestion. Conversion from Traditional to SI units: Cholesterol: $1 \mathrm{mg} / \mathrm{dl} \bumpeq$ $0.02586 \mathrm{mmol} / 1$; triglyceride: $1 \mathrm{mg} / \mathrm{dl} \bumpeq 0.0113 \mathrm{mmol} / 1$.

pain had operation within 24 hours of coronary angiography. These latter patients had continuous electrocardiographic monitoring and regular sublingual trinitrin to relieve chest pain in the interval between angiography and surgery, but in no case was it considered necessary to use balloon counterpulsation.

Great care was taken to avoid any fall in blood pressure during induction of anaesthesia, and where necessary pressor agents were used. In all cases the heart was prepared for bypass as quickly as possible. Once on bypass the major division of the left coronary artery was prepared and an anastomosis, using either the left internal mammary artery or a long saphenous vein, was carried out. Occasionally an endarterectomy was performed first. If a vein was used it was immediately anastomosed to the aorta to establish coronary flow as quickly as possible. The other diseased arteries were grafted as necessary. Normothermic bypass was used throughout, together with elective fibrillation and aortic crossclamping for periods up to 15 minutes as required.

The patients were seen at three months, six months, and then yearly after operation. Exercise tests were performed at each visit. 

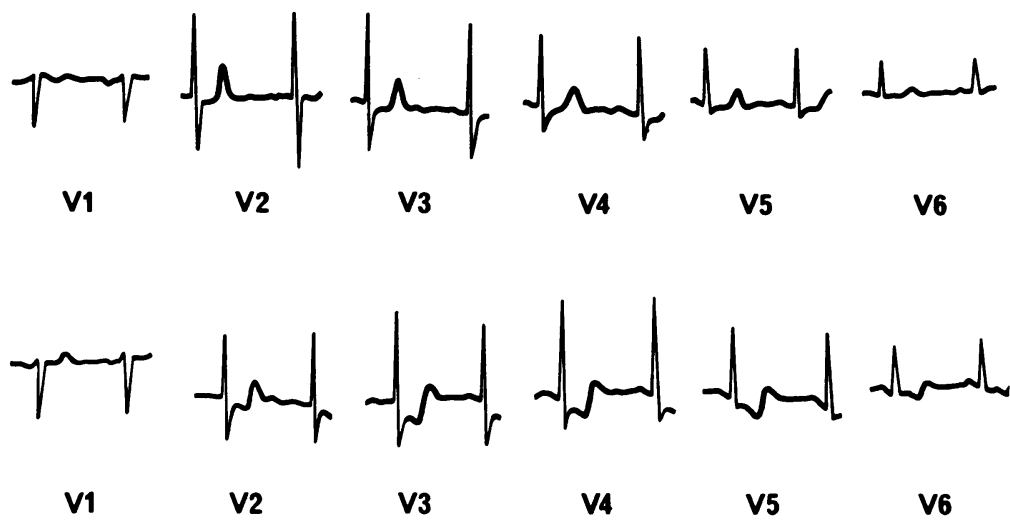

FIG. 1 Transient ST depression occurring at rest during angina.

TABLE 2

\begin{tabular}{|c|c|c|c|c|c|}
\hline \multirow[b]{2}{*}{ Case no. } & \multirow{2}{*}{$\begin{array}{l}\text { Duration of } \\
\text { follow-up } \\
\text { (mth) }\end{array}$} & \multicolumn{2}{|l|}{ Angina grade } & \multicolumn{2}{|c|}{ Maximum exercise load and end-point ( $\mathrm{kpm} / \mathrm{min})$} \\
\hline & & Preoperative & Postoperative & Preoperative & Postoperative \\
\hline 1 & 21 & 3 & 0 & 600 , angina & 1050 , fatigue \\
\hline 2 & 14 & 4 & 0 & 600, ST depression and angina & 750 , fatigue and dyspnoea \\
\hline 3 & 12 & 2 & 1 & 600 , dyspnoea & 750 , fatigue and dyspnoea \\
\hline 4 & 9 & 2 & 0 & Not done & 450 , fatigue \\
\hline $5+$ & - & 4 & - & 600, ST depression and fatigue & Died awaiting operation \\
\hline 6 & 6 & 3 & 0 & 150 , dyspnoea and fatigue & 300 , fatigue \\
\hline 7 & 7 & 3 & 0 & Not done & 600 , fatigue \\
\hline 8 & 9 & 3 & 0 & 450, dyspnoea & 750 , dyspnoea \\
\hline 9 & 10 & 2 & 0 & 450 , angina & 600 , fatigue and dyspnoea \\
\hline 10 & 35 & 4 & 0 & Rest pain & 600 , dyspnoea and ST depression \\
\hline 11 & 24 & 2 & 0 & 600 , angina & 750 , fatigue \\
\hline 12 & 18 & 2 & 0 & 450 , angina & 600 , fatigue \\
\hline 13 & 19 & 4 & 0 & Not done & 600 , fatigue \\
\hline $14+$ & - & 4 & 一 & Rest pain & Died at operation \\
\hline 15 & 18 & 3 & 0 & 300, ST depression and angina & $\begin{array}{l}600 \text {, dyspnoea, fatigue and ST } \\
\text { depression }\end{array}$ \\
\hline 16 & 4 & 2 & Non-surgical & & \\
\hline 17 & 4 & 4 & 0 & 600 , angina & 600 , fatigue \\
\hline 18 & 3 & 4 & 0 & Rest pain & Not done \\
\hline 19 & 3 & 2 & 0 & Not done & 1050 , fatigue \\
\hline 20 & 3 & 4 & 0 & Rest pain & 900 , fatigue \\
\hline
\end{tabular}

tHospital death. $1 \mathrm{kpm} / \mathrm{min}=0.1635$ Watt

episodes of rest pain. Fig. 1 shows intermittent ST depression at rest in Case 18. Four patients had cardiomegaly on chest $x$-ray. Twelve had been treated with sublingual trinitrin and 12 with betaadrenergic blocking agents.

Eleven patients performed the exercise test before operation (Table 2). The mean maximum exercise level achieved was $490 \mathrm{kpm} / \mathrm{min}(80.1$ Watts) with a range of $150(24.5 \mathrm{Watts})$ to $600 \mathrm{kpm} / \mathrm{min}(98.1$ Watts). The end-point in eight of these was angina and in three it was dyspnoea. Three of the patients who were limited by angina developed ST depression of $2 \mathrm{~mm}$ or more at end-point.
Cardiac catheterization data are shown in Table 3. Eleven patients underwent the pacing stress test during catheterization. Angina was induced in these at heart rates ranging from 100 to 170 beats per minute. Five other patients had angina at rest during catheterization. The resting left ventricular end-diastolic pressures ranged from 5 to $48 \mathrm{mmHg}$ $(0.7$ to $6.4 \mathrm{kPa})$, with a mean of $16 \mathrm{mmHg}(2.1$ $\mathrm{kPa}$.

The left ventriculogram was normal in 9 patients. Five had a grade 1, 3 a grade 2, and 2 a grade 3 abnormality on their ventriculogram. Only 1 patient had diffuse left ventricular dysfunction (grade 4). 
TABLE 3

\begin{tabular}{|c|c|c|c|c|c|c|}
\hline \multirow[b]{2}{*}{ Case no. } & \multirow{2}{*}{$\begin{array}{l}\text { Left ventricular end } \\
\text { diastolic pressure } \\
\text { (mmHg) }\end{array}$} & \multirow{2}{*}{$\begin{array}{l}\text { Maximum pacing } \\
\text { rate (beats/min) } \\
\text { at angina }\end{array}$} & \multicolumn{3}{|c|}{ Coronary arteries: grading of disease $\uparrow$} & \multirow[b]{2}{*}{$\begin{array}{l}\text { Left ventricular } \\
\text { angiographic grade }\end{array}$} \\
\hline & & & $\begin{array}{l}\text { Left anterior } \\
\text { descending }\end{array}$ & Left circumflex & Right & \\
\hline 1 & 17 & 150 & $2^{\mathrm{m}}$ & $3 \star$ & 1 & 1 \\
\hline 2 & 5 & 170 & $2 \star$ & 4 * & 0 & 0 \\
\hline 3 & 17 & 150 & $3 *$ & $3 \star$ & $3 \star$ & 1 \\
\hline 4 & 12 & Rest pain & $2 \star$ & 3 & $4 \star$ & 2 \\
\hline 5 & 16 & 100 & 3 & 0 & 1 & 0 \\
\hline 6 & 25 & Not done & $3 \star$ & 1 & $4 *$ & 3 \\
\hline 7 & 25 & Not done & 2 * & $2 \star$ & $3 * \mathbf{E}$ & 1 \\
\hline 8 & 7 & 150 & $4 \star E$ & 2 & $4 \star \bar{E}$ & 0 \\
\hline 9 & 15 & 150 & $3 *$ & $3 *$ & $3 \star$ & 1 \\
\hline 10 & 48 & Rest pain & 0 * & $0 \star$ & 3 & 2 \\
\hline 11 & 7 & 110 & $3 \star$ & $3 \star$ & 2 & $\mathbf{0}$ \\
\hline 12 & 10 & 170 & $4^{\star}$ & 0 * & 2 & 2 \\
\hline 13 & 10 & 130 & $3 \star$ & 3 & 3 & 0 \\
\hline 14 & 18 & Rest pain & $1 *$ & $3 *$ & 2 & 0 \\
\hline 15 & 10 & 150 & $3^{\mathrm{m}}$ & $3 \star$ & $4 \star$ & 1 \\
\hline 16 & 18 & Not done & 3 & 4 & 4 & 4 \\
\hline 17 & 26 & 150 & $D \star 4 *$ & 3 & $4^{\star}$ & 3 \\
\hline 18 & 8 & Rest pain & 2 & 2 * & $3 \star$ & 0 \\
\hline 19 & 12 & Not done & $3 \star$ & $3 *$ & 0 & 0 \\
\hline 20 & 20 & Rest pain & $D * 3 *$ & $3 *$ & $2^{\star}$ & 0 \\
\hline
\end{tabular}

Conversion from traditional to SI units: $1 \mathrm{~mm} \mathrm{Hg} \approx 0.133 \mathrm{kPa}$

tAll patients had grade 3 stenosis of left main coronary artery

$\mathrm{m}$, vessel bypassed with left internal mammary artery

$\star$, vessel bypassed with saphenous vein

$E$, endarterectomy

D, diagonal branch left anterior descending grafted

All had at least one other major lesion (grade 3 or 4) in the coronary tree besides the left main coronary artery stenosis. Six patients had lesions of 2 other vessels and a further 6 had lesions of 3 vessels. The right coronary artery was affected in 12 . There was radiographic calcification in the region of the left main stem in only 3 patients (Cases 1,16 , and 19). There were no major complications associated with the investigation.

One patient (Case 5) had a fatal myocardial infarction in hospital while awaiting operation. Another patient (Case 16) who presented with dyspnoea was considered unsuitable for surgery, because of diffuse left ventricular hypokinesia.

Eighteen patients had surgical treatment. The vessels bypassed and the types of graft used are indicated in Table 3. One patient had a single graft, 11 had double, 5 had triple, and 1 quadruple grafts. A prior endarterectomy was performed on 3 vessels and the left internal mammary artery was used twice. The graft flow was measured in 24 vessels and ranged from 30 to $140 \mathrm{ml} / \mathrm{min}$, with a mean of $78 \mathrm{ml} / \mathrm{min}$.

One patient (Case 14) became hypotensive during induction of anaesthesia and developed resistant ventricular fibrillation. At thoracotomy a large portion of the left ventricle in the region supplied by the left coronary artery was non-contractile. A double coronary artery graft was performed but the patient did not survive operation.

The follow-up data are shown in Table 2. The mean duration of follow-up is $12 \cdot 2$ months. There have been no late deaths or myocardial infarctions. Only one patient (Case 3) of the 17 surgical survivors has angina. Sixteen patients have had postoperative exercise tests. The mean maximum level achieved after operation was $684 \mathrm{kpm} / \mathrm{min}(111.8$ Watts), with a range of 300 to $1050 \mathrm{kpm} / \mathrm{min}$ (49 to 171.7 Watts). In Fig. 2 a comparison of the mean preoperative with the latest postoperative exercise level achieved by 10 patients indicates a significant improvement in performance. The 6 patients who did not have a preoperative exercise test have a mean postoperative exercise performance of $700 \mathrm{kpm} / \mathrm{min}$ (114.5 Watts).

\section{Discussion}

The incidence of left main coronary artery stenosis among patients investigated for coronary artery disease in our department is 3 per cent. Wolfson, Grant, and Ross (1973), who also reported on left 


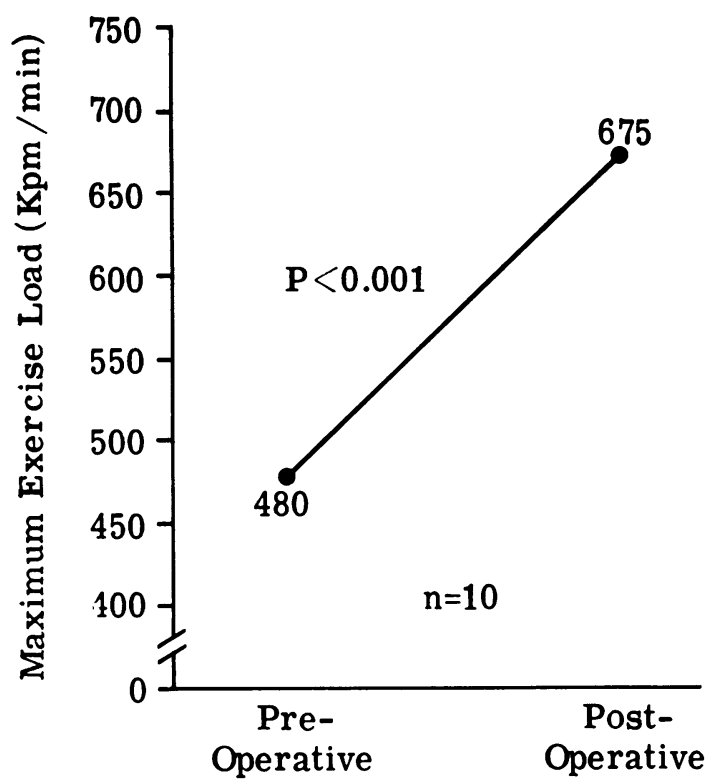

FIG. 2 The results of pre-and post-operative exercise tests.

main coronary artery stenoses of 75 per cent or greater, found a similar incidence. Other authors (Cohen et al., 1972; Khaja et al., 1974; Proudfit, Shirey, and Sones, 1967) who reported on stenoses of more than 50 per cent found an overall incidence varying from 2.5 to 5.9 per cent.

The majority of our patients had severe angina. Cohen et al. (1972) while recognizing that there were no features specific to left main coronary artery stenosis, suggested it could be anticipated before angiography in patients showing a 'profound ischaemic response' on their electrocardiogram during exercise. 82 per cent of their group and 77 per cent of Khaja's group had a positive exercise test. Only 27 per cent of our group who exercised on a bicycle ergometer developed ST depression. This discrepancy may be related to the method of exercise testing used, or to the fact that we recorded from a single praecordial lead.

Major coronary lesions other than left main coronary artery stenosis were present in all our patients. This is the usual finding both at coronary angiography (Lavine et al., 1972; Rosch et al., 1973) and at necropsy (Bulkley and Roberts, 1974). Lavine et al. (1972) in their report comment that the clinical features of these patients may be as much a reflection of the generalized coronary artery disease as of the left main coronary artery lesion.

The risk of coronary angiography in these patients is well known (Cohen et al., 1972; Lavine et al.,
1972). Some authors (Cohen et al., 1972; Rosch et al., 1973) have suggested a preliminary test injection in the left posterior sinus of Valsalva in patients with suspected left main coronary artery disease. As indicated above, however, we were seldom able to predict from clinical findings, exercise testing, or other parameters, those patients likely to have left main coronary artery stenosis. Nevertheless, there were no major complications and no fatalities associated with angiography in this series, nor in other recently reported series (Khaja et al., 1974; Zeft et al., 1974).

Surgical mortality for left main coronary artery stenosis from the reported series ranges from 8.2 to 39 per cent (Pichard et al., 1973; Zeft et al., 1974; Khaja et al., 1974; Cohen et al., 1972; Kisslo et al., 1973). The surgical mortality for our group (5.5 per cent) lies between our overall figures of 1.9 per cent for patients with effort angina and 12.5 per cent for patients with cardiac pain at rest. Hypotension during induction of anaesthesia is a recognized hazard in these patients (Cohen et al., 1972). The surgical death in our group was related to this complication, though precautions had been taken to avoid it. The striking symptomatic improvement among the surgically treated group has been mirrored in their improved exercise performance.

Our studies have led us to the conclusion that patients with left main coronary artery stenosis also have severe coronary lesions elsewhere but behave no differently from other patients with severe coronary artery disease, either from the clinical and investigative point of view, or in their distinct symptomatic improvement with surgical treatment.

\section{References}

Balcon, R., Honey, M., Rickards, A. F., Sturridge, M. F., Walsh, W., Wilkinson, R. K., and Wright, J. E. C. (1974). Evaluation by exercise testing and atrial packing of results of aorto-coronary bypass surgery. British Heart fournal, 36, 841 .

Bruschke, A. V. G., Proudfit, W. L., and Sones, F. M., Jr. (1973). Progress study of 590 consecutive non-surgical cases of coronary disease followed 5-9 years; 1 . Arteriographic correlations. Circulation, 47, 1147.

Bulkley, B. H., and Roberts, W. C. (1974). Severe (75 per cent) narrowing of left main coronary artery: an indication of generalized severe coronary artherosclerosis (abstract). 7th World Congress of Cardiology 1974 Abstr. 326 Bis.

Cohen, M. V., Cohn, P. F., Herman, M. V., and Gorlin, R. (1972). Diagnosis and prognosis of main left coronary artery obstruction. Circulation, 45 and 46, Suppl. 1, 57 .

Khaja, F., Sharma, S. D., Easley, R. M., Heinle, R. A., and Goldstein, S. (1974). Left main coronary artery lesions: risks of catheterization, exercise testing and surgery. Circulation, 50, Suppl. 2, 136.

Kisslo, J., Peter, R., Behar, V., Bartel, A., and Kong, Y. (1973). Left main coronary artery stenosis (abstract). Circulation, 48, Suppl. 4, 57. 
Lavine, P., Kimbiris, D., Segal, B. L., and Linhart, J. W. (1972). Left main coronary artery disease. Clinical arteriographic and hemodynamic appraisal. American fournal of Cardiology, 30, 791.

McConahay, D. R., McCallister, B. D., Hallerman, F. J., and Smith, R. E. (1970). Comparative quantitative analysis of the electrocardiogram and the vectorcardiogram. Circulation, 42, 245.

Pichard, A. D., Sheldon, W. C., Shinji, K., Effler, D. B., and Sones, F. M., Jr. (1973). Severe arteriosclerotic obstruction of the left main coronary artery: follow up results in 176 patients (abstract). Circulation, 48, Suppl. 4, 53.

Proudfit, W. L., Shirey, E. K., and Sones, F. M., Jr. (1967). Distribution of arterial lesions demonstrated by selective cinecoronary arteriography. Circulation, 36, 54.

Rosch, J. DeMots, H., Antonovic, R., Rahimtoola, S. H., and Judkins, M. P. (1973). Coronary arteriography in left main-coronary artery disease (abstract). Circulation, 48, Suppl. 4, 209.
Webster, S., Moberg, C., and Rincon, G. (1974). Natural history of severe proximal coronary artery disease as documented by coronary cineangiography. American fournal of Cardiology, 33, 195.

Wolfson, S., Grant, D., Ross, A. M., and Cohen, L. S. (1973). Risk of death related to coronary arteriography: role of left coronary lesions (abstract). Circulation, 48, Suppl. 4, 88.

World Health Organization (1970). Classification of hyperlipidaemias and hyperlipoproteinaemias. Bulletin of the World Health Organization, 43, 891.

Zeft, H. J., Manley, J. C., Huston, J. H., Tector, A. J., Auer, J. E., and Johnson, W. D. (1974). Left main coronary artery stenosis: results of coronary bypass surgery. Circulation, 49, 68.

Requests for reprin ts to Dr. S. O. Banim, London Chest Hospital, Bonner Road, London E2 9JX. 